\title{
Molecular Analysis of $S$-haplotypes in Peach, a Self-compatible Prunus Species
}

\author{
Attila Hegedüs ${ }^{1}$ \\ Department of Applied Chemistry, Faculty of Food Science, Corvinus University of Budapest, P.O. Box \\ 53, Budapest, H-1518, Hungary \\ Zoltán Szabó and József Nyéki \\ Center of Agricultural Sciences, Institute for Extension and Development, University of Debrecen, \\ Böszörményi út 138, Debrecen, H-4032, Hungary \\ Júlia Halász and Andrzej Pedryc \\ Department of Genetics and Plant Breeding, Faculty of Horticultural Science, Corvinus University of \\ Budapest, P.O. Box 53, Budapest, H-1518, Hungary
}

\begin{abstract}
Additional INDEX wORDs. DNA sequencing, F-box, modifier genes, non-equilibrium $\mathrm{pH}$ gradient electrofocusing, PCR analysis, Prunus persica, ribonuclease, $S$-allele

Abstract. The most commercially grown peach [Prunus persica (L.) Batsch.] cultivars do not require cross-pollination for reasonable fruit set; however, self-incompatibility is a well-known feature within the Prunoideae subfamily. Isoelectric focusing and native polyacrylamide gel electrophoresis of $S$-ribonucleases; PCR analyses of $S$-RNase and $S$-haplotype-specific F-box genes as well as DNA sequencing were carried out to survey the self-(in)compatibility allele pool and to uncover the nature of self-compatibility in peach. From 25 cultivars and hybrids with considerable diversity in phenotype and origin, only two $S$-haplotypes were detected. Allele identity could be checked by exact length determination of the PCR-amplified fragments and/or partial sequencing of the peach $S_{1^{-}}, S_{2}-$, and Prunus davidiana (Carr.) Franch. $S_{1}$-RNases. $S$-RNases of peach were detected to possess ribonuclease activity, and a single nucleotide polymorphism in the $S_{1}$-RNase was shown, which represents a synonymous substitution and does not change the amino acid present at the position in the protein. A 700-bp fragment of the peach SFB gene was PCR-amplified, which is similar to the fragment size of functional Prunus L. SFBs. All data obtained in this study may support the contribution of genes outside the $S$-locus to the self-compatible phenotype of peaches.
\end{abstract}

Most Prunus species are self-incompatible (SI), implying that pollens in the self-pistils are not able to achieve successful fertilization (de Nettancourt, 2001). This trait is of the gametophytic type and helps to avoid inbreeding, which would result in increased homozygosity and a greater chance for lethal alleles appearing in the homozygous condition. The self-incompatible phenotype of Prunus species is controlled by a single multiallelic locus, the $S$-locus, which is a multigene complex, as the recognition process takes place between the pistil-expressed ribonuclease enzyme ( $S$-RNase) and the pollen-expressed $S$-haplotype-specific F-box molecule (SFB) (Kao and Tsukamoto, 2004).

Self-compatibility, however, is a well-known property, even in the Rosaceae family, which is highly appreciated by growers. In 'Osa-Nijisseiki', a self-compatible (SC) cultivar of japanese pear (Pyrus serotina Rehd.) (Sassa et al., 1992) and in all characterized SC cultivars of almond [Prunus dulcis (Mill.) D.A. Webb.] (Boškovic' et al., 1999), the self-fruitful phenotype is either due to the failure of protein expression or the loss of ribonuclease activity of the transcribed proteins. Self-compatibility may also be the consequence of a mutation within the pollen F-box gene, as was verified in sweet cherry (Prunus avium L.) (Sonneveld et al., 2005; Ushijima et al., 2004), and japanese apricot (Prunus

Received for publication 7 Apr. 2006. Accepted for publication 15 July 2006. This work was supported by the OM-00063/2004 grant. We acknowledge Gábor Drén and László Szalay for their assistance in collecting the plant material. We thank László Palkovics for making the DNA sequencing possible; Éva Stefanovits-Bányai for the kind support; and Pedro Martínez-Gómez for the helpful discussions.

1Requests for reprints should be addressed to: hegedus.attila@uni-corvinus.hu mume Sieb. et Zucc.) (Ushijima et al., 2004), and hypothesized in apricot (Prunus armeniaca L.) (Halász et al., 2005). Classic and molecular genetic studies have revealed the existence of genes outside the $S$-locus that are required for the SI response in the Solanaceae L. (Ai et al., 1991; Kao and Tsukamoto, 2004); however, there are no data on the action of similar modifier genes in any Prunus species.

The function of the $S$-locus in Prunus persica is completely unexplored. The reason may lie in the fact that most peach cultivars are self-compatible (Cullinan, 1937; Szabó and Nyéki, 2000) and only a few self-sterile cultivars are known, since many of them have been eliminated from the market regardless of their favorable properties, because pollinizer cultivars were required for reasonable yields. All described fruit set failures of peaches are attributable to male sterility controlled by a single recessive gene that does not reside in the $S$-locus (Dirlewanger et al., 1998; Scott and Weinberger, 1944).

In peaches, two stigmatic RNases were detected by SDSPAGE, from which a $21-\mathrm{kDa}$ isozyme was found to significantly inhibit pollen tube growth in a developmentally regulated way, reaching maximum activity at the beginning of anthesis (Roiz and Shoseyov, 1995). Its action on pollen tubes was completely eliminated by the application of torula yeast RNA as a competitive inhibitor of the RNase enzyme.

The objective of this research was to survey the self(in)compatibility allele pool in peach cultivars by $S$-RNase detection, $S$-gene specific PCR, and DNA sequencing; as well as to raise hypotheses on the function of the $S$-locus in peach as compared to the SC cultivars of self-incompatible Prunus species. 
Table 1. Main phenotypic characteristics, origin and $S$-genotypes of the tested self-compatible peach cultivars.

\begin{tabular}{|c|c|c|c|c|c|c|c|}
\hline Cultivar & Type & Flesh color & Fruit shape & Stone & Origin & Pedigree & $\overline{S \text {-genotype }}$ \\
\hline Babygold 6 & Peach & Yellow & Round & Cling & U.S. & Seedling from open pollination & $S_{1} S_{1}$ \\
\hline Babygold 7 & Peach & Yellow & Round & Cling & U.S. & $\begin{array}{l}\text { (Lemon Free x P.I.35201) } \\
\text { x (J.H. Hale x Goldfinch) }\end{array}$ & $S_{1} S_{1}$ \\
\hline Bigtop & Nectarin & Yellow & Round & Cling & U.S. & Unknown cross & $S_{1} S_{1}$ \\
\hline Caldesi 2000 & Nectarin & White & Round & Semifree & Italy & Stark Redgold x Snow Queen & $S_{1} S_{1}$ \\
\hline Dixired & Peach & Yellow & Round & Cling & U.S. & Self-pollination of Halehaven & $S_{1} S_{1}$ \\
\hline Early Redhaven & Peach & Yellow & Round & Semifree & U.S. & Bud mutation of Redhaven & $S_{1} S_{1}$ \\
\hline Elberta & Peach & Yellow & Round & Free & U.S. & Chinese Cling x Early Crawford (?) & $S_{1} S_{1}$ \\
\hline Flamekist & Nectarin & Yellow & Round & Cling & U.S. & Self-pollination of Gold King & $S_{2} S_{2}$ \\
\hline Hybrid 1 & Nectarin & White & Round & Free & Hungary & Unknown & $S_{1} S_{2}$ \\
\hline Hybrid 2 & Nectarin & Yellow & Round & Free & Hungary & Unknown & $S_{2} S_{2}$ \\
\hline Incrocio Pieri & Peach & White & Round & Free & Italy & Elberta x Santa Anna & $S_{1} S_{1}$ \\
\hline Mariska & Peach & White & Round & Semifree & Hungary & Local cultivar with unknown origin & $S_{1} S_{1}$ \\
\hline Meigue Pantao & Peach & White & Flat & Cling & China & Unknown & $S_{1} S_{1}$ \\
\hline Meystar & Peach & White & Round & Free & France & Seedling from open pollination & $S_{1} S_{1}$ \\
\hline Michelini & Peach & White & Round & Free & Italy & Unknown & $S_{1} S_{1}$ \\
\hline Padana & Peach & Yellow & Round & Free & Italy & Fayette $x$ Fairtime & $S_{1} S_{1}$ \\
\hline Piroska & Peach & White & Round & Free & Hungary & Local cultivar with unknown origin & $S_{2} S_{2}$ \\
\hline Redcal & Peach & Yellow & Round & Free & U.S. & Self-pollination of hybrid 31-21 & $S_{1} S_{1}$ \\
\hline Remény & Peach & White & Flat & Free & Hungary & Ford $x$ Pantao & $S_{1} S_{1}$ \\
\hline Rikakusuimitsu & Peach & White & Round & Free & Japan & Open pollination from Shanghaj suimi & $S_{1} S_{1}$ \\
\hline Sensation & Peach & Yellow & Round & Free & U.S. & Unknown & $S_{1} S_{1}$ \\
\hline Snow Queen & Nectarin & White & Round & Free & U.S. & Unknown & $S_{1} S_{1}$ \\
\hline Stark Redgold & Nectarin & Yellow & Round & Free & U.S. & Open pollination from Sun Grand & $S_{1} S_{1}$ \\
\hline Suncrest & Peach & Yellow & Round & Free & U.S. & Alamar x Gold Dust & $S_{1} S_{1}$ \\
\hline Symphony & Peach & Yellow & Round & Free & U.S. & Open pollination from Early O’Henry & $S_{1} S_{1}$ \\
\hline
\end{tabular}

\section{Materials and Methods}

Plant Material. Twenty-five peach cultivars and hybrids of diverse type and origin were used in the experiments (Table 1) as well as a $P$. persica $\times$ P. davidiana hybrid originating from a rootstock breeding program. Ten accessions were obtained from the orchard at Boldogkováralja, 10 from Siófok, and five from the peach germplasm collection of the Corvinus University of Budapest, Department of Pomology, in Szigetcsép, Hungary.

NATIVE POLYACRYLAMide GEL ELECTROPHORESIS (PAGE) AND ELECTROFOCUSING. About 40 styles were harvested just before or soon after anthesis. For native PAGE, an extraction buffer was used containing $0.1 \mathrm{M} \mathrm{K}$-phosphate ( $\mathrm{pH} 7.8), 1 \mathrm{~mm}$ phenylmethanesulfonyl fluoride, $2 \mathrm{~mm}$ diethylenetriaminepentaacetic acid, $1 \mathrm{~mm}$ dithiothreitol, and $5 \mathrm{~mm}$ ascorbic acid, while the extraction procedure of stylar ribonucleases for non-equilibrium $\mathrm{pH}$ gradient electrofocusing (NEpHGE) was carried out as described for cherry by Boškovic' and Tobutt (1996). The homogenates were centrifuged $\left(-4^{\circ} \mathrm{C}, 35 \mathrm{~min}, 18,750 g_{\mathrm{n}}\right)$ with a Mikro $22 \mathrm{R}$ device (Hettich Zentrifugen, Tuttlingen, Germany). Supernatant stored at $-80{ }^{\circ} \mathrm{C}$ was used for further analyses.

Native PAGE and molecular weight determination with the use of Ferguson plots were carried out according to the Technical Bulletin of Nondenatured Protein Molecular Weight Marker Kit (Sigma, Budapest, Hungary). Pistil proteins were stained for RNase activity and marker proteins were stained by Coomassie Brilliant Blue R.

Non-equilibrium pH gradient electrofocusing was carried out according to the protocol NEpHGE I described for apricot (Halász et al., 2005). After a 30-min prefocusing at $100 \mathrm{~V}$, the samples, $40 \mu \mathrm{L}$, were loaded at the anodal end, and the focusing run comprised $1 \mathrm{~h}$ at $130 \mathrm{~V}, 2 \mathrm{~h}$ at $260 \mathrm{~V}, 1 \mathrm{~h}$ at $350 \mathrm{~V}$, and $1 \mathrm{~h}$ at
$450 \mathrm{~V}$. To determine $\mathrm{pI}$ values, standard proteins with pI points from 5.9 to 9.3 (Sigma) were run alongside the samples in gels containing 4\% Pharmalyte $\mathrm{pH} 3-10$ and 1.2\% Ampholine $\mathrm{pH}$ 9-10.5 according to the program described for apricot (Halász et al., 2005). The pI markers were stained with Coomassie Blue. The catalyte and analyte used were $0.1 \mathrm{~m}$ sodium hydroxide and $0.04 \mathrm{M}$ DL-glutamic acid, respectively. The temperature was maintained at $4{ }^{\circ} \mathrm{C}$. Gels were stained for RNase activity as described by Boškovic' and Tobutt (1996).

DNA EXTRACTION AND S-PCR ANALYSES. Genomic DNA was extracted from fully expanded young leaves using the DNeasy Plant Mini Kit (Qiagen, Hilden, Germany). DNA concentrations were measured using a spectrophotometer GeneQuant II RNA/DNA Calculator (Pharmacia Biotech, Budapest, Hungary).

PCR was conducted according to Sutherland et al. (2004) using the degenerate primers EM-PC2consFD and EM-PC3consRD for the amplification of the second intron region. To amplify the first intron, the fluorescently labeled forward primer PaConsI-F(Ortega et al., 2005; Sonneveld et al., 2003) was used in combination with the reverse primer EM-PC1consRD (Ortega et al., 2005). PCR was carried out in a PTC 200 thermocycler (MJ Research, Budapest, Hungary) using the program described for the primers (Ortega et al., 2005; Sutherland et al., 2004). A fragment of the SFB was PCR-amplified according to Romero et al. (2004) with the primers SFBc-F and SFBc-R designed from the consensus sequence of Prunus SFB alleles. Approximately 20-80 ng of genomic DNA was used for PCR amplification in a $25-\mu \mathrm{L}$ reaction volume, containing $1 \times$ PCR buffer (Sigma, Budapest, Hungary) with final concentrations of $10 \mathrm{~mm}$ Tris- $\mathrm{HCl}(\mathrm{pH} 8.3), 50 \mathrm{~mm}$ $\mathrm{KCl}, 1.5 \mathrm{~mm} \mathrm{MgCl}_{2}, 0.2 \mathrm{~mm}$ of dNTPs, $0.4 \mu \mathrm{M}$ of the adequate primers, and $0.625 \mathrm{U}$ of Taq DNA polymerase (Sigma). PCR products were separated by electrophoresis in $2 \%$ TAE agarose 
gels for $2 \mathrm{~h}$ at $100 \mathrm{~V}$ and DNA bands were visualized by ethidium bromide staining.

Cloning, SEQuencing, AND ANAlyses of DNA SEQuences. Fragment length of the second intron region products were estimated by comparison with the 1-kbp DNA ladder (Promega, Madison, Wis.). To determine the exact size of the first intron region fragments under $500 \mathrm{bp}$, the fluorescently labeled products were run in an automated sequencer ABI PRISM 3100 Genetic Analyzer (Applied Biosystems, Budapest, Hungary). PCR products were cloned into a pGEM-T Easy vector (Promega) and sequenced in the above-described sequencer. For each allele, the nucleotide sequences of three clones were determined in both directions. DNA sequences were submitted to the GenBank/EMBL/DDBJ database under the accession numbers DQ269993 ( $S_{1 \mathrm{~m}}$-RNase), DQ269994 ( $S_{1}$-RNase), DQ376142 ( $S_{2}$-RNase), and DQ386736 ( $P$. davidiana $\left.S_{1}-\mathrm{RNase}\right)$. Analyses of DNA and deduced amino acid sequence data were performed using BLAST at NCBI (Altschul et al., 1997) and the CLUSTAL W program (Higgins et al., 1994).

\section{Results and Discussion}

Cultivars used in this study were previously characterized as being self- and cross-compatible (Miller et al., 1989; Szabó and Nyéki, 2000). In the stylar extracts of peach cultivars and hybrids representing different types and origins (Table 1), NEpHGE has revealed only two different $S$-ribonuclease bands (Fig. 1A). One of them was present in 22 peach cultivars (we propose designating this allele as $S_{1}$ ), while the other one could only be found in four accessions (labeled as $S_{2}$ ). Most of the cultivars and hybrids possessed only one RNase izozyme, which may be due to an inappropriate separation of the isozymes, the presence of a null allele, or a homozygote state at the locus. As shown in Fig. 1 B and $\mathrm{C}$, this latter seems more possible since PCR amplification with Prunus consensus primers for the first (Ortega et al., 2005; Sonneveld etal., 2003) and second (Sutherland et al., 2004) introns and parts of the flanking exon regions within the $S$-RNase gene also revealed a sole fragment. Their exact sizes were assessed with fluorescently labeled primers or DNA sequencing. Primers amplifying the first intron yielded a 405-bp-long DNA fragment for the $S_{1}$-allele. Second intron amplification of $S_{1}$ yielded fragments of $532 \mathrm{bp}$ in length. The first intron amplification product was smaller (207 bp), while the second intron amplification yielded a longer fragment (1272 bp) as compared to the $S_{1}$ (Fig. 1B-C). Besides intron lengths, the deduced amino acid sequence of the hypervariable region of $S_{2}$-allele was also different to a considerable extent from that of the $S_{1}$-allele (Fig. 2). The proportion of hydrophilic amino acids included in the hypervariable region ranged between $61 \%$ and $69 \%$, similarly to almond $S$-RNases (Ushijima et al., 1998), implying that these are exposed at the surface of the folded protein and play an important role in the discrimination of self from non-self pollen. The only heterozygote genotype $\left(S_{1} S_{2}\right)$ was recorded in a hybrid of unknown origin.

Martínez-Gómez et al. (2003a) applied $S$-gene specific PCR

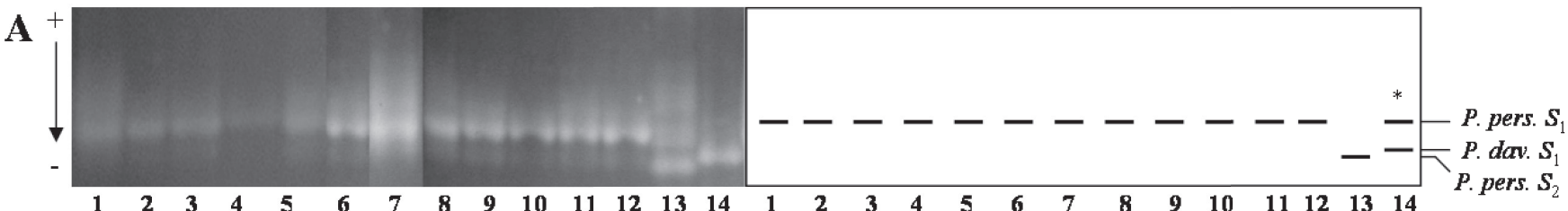

B
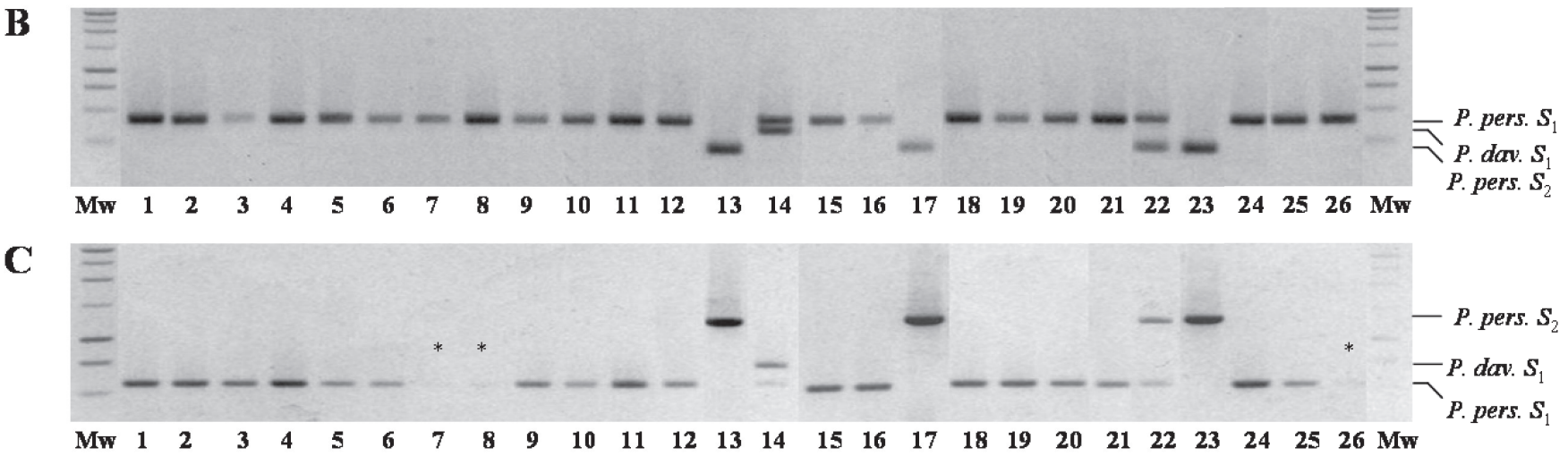

D

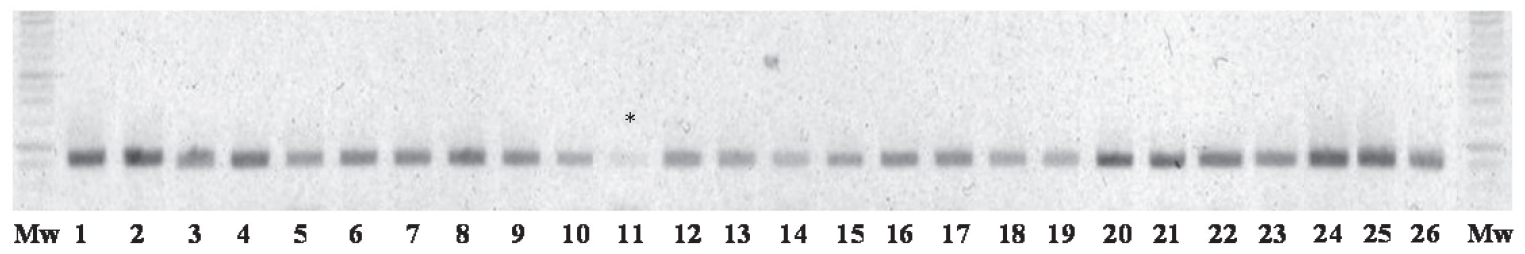

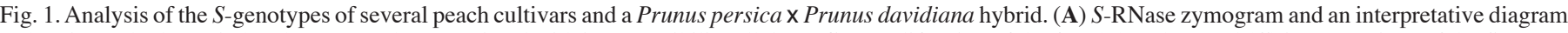

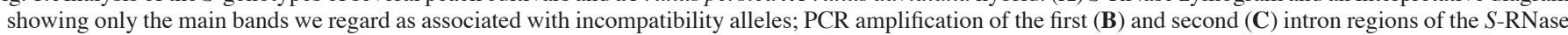

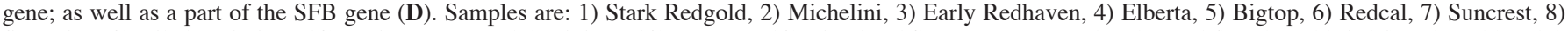

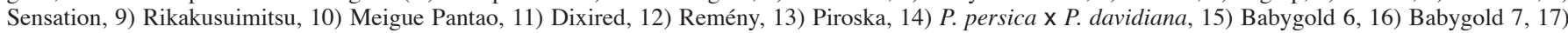

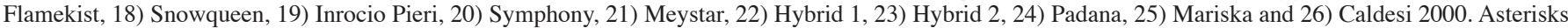
indicate faint but visible bands. 


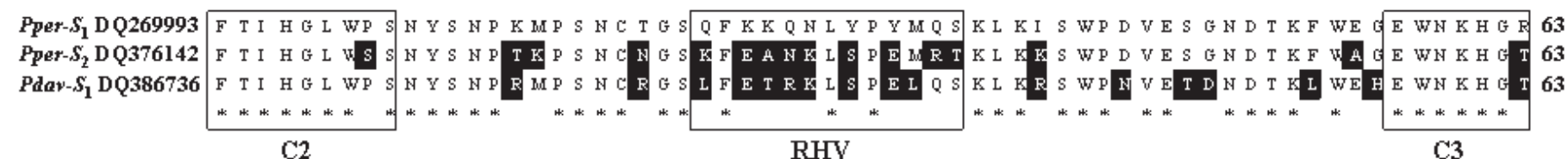

Fig. 2. Alignment of the deduced amino acid sequences of partial $S$-RNase genes from peach $\left(\right.$ Pper- $S_{1}$ and $\left.S_{2}\right)$ and Prunus persica $\times$ Prunus davidiana $\left(\right.$ Pdav- $\left.S_{1}\right)$. Sequences were aligned using CLUSTAL W (Higgins et al., 1994). Asterisks indicate conserved sites. Conserved regions (C2 and C3) and the hypervariable region (RHV) are boxed.

markers to analyze the progeny of an almond $x$ peach interspecific cross, and they could also amplify only one allele from the tested peach accession. Alow level of polymorphism is not surprising in a self-compatible species as the narrow genetic basis, inbreeding, and co-ancestry of peach cultivars have been demonstrated many times (Arulsekar et al., 1986; Dirlewanger et al., 1998; Faust and Timon, 1995; Martínez-Gómez et al., 2003b, 2003c; Scorza et al., 1985). Furthermore, successive self-pollinations in peach breeding programs are readily used to eliminate unfavorable agronomic characters, because decline in the fruit weight or any other inbreeding effect that may occur in almond could not be observed in peach (Dicenta et al., 2002; Monet et al., 1996).

Our results suggest that self-compatibility in peaches is not a consequence of the activity loss of $S$-RNases, as in the case of SC cultivars of almond and japanese pear (Boškovic' et al., 1999; Sassa et al., 1992), where alleles for self-compatibility do not code for RNase activity. Two stigmatic RNases were identified in the peach cultivar Texas by Roiz and Shoseyov (1995), who concluded, based on their in vitro pollen tube growth studies, that only one of the two isozymes played a role in the pollination process. The molecular weight of this RNase was determined with SDS-PAGE to be $21 \mathrm{kDa}$. We have determined the isoelectric point of the $S_{1}$-RNase and the pI 9.94 value was very similar to that of other rosaceous $S$-RNases (Hegedüs et al., 2007). Its molecular weight proved to be $\sim 40 \mathrm{kDa}$, which is higher than the value measured by Roiz and Shoseyov (1995); however, it falls within the range of 30-40 kDa obtained for almond and sweet cherry $S$-RNases (Mau et al., 1982; Tao et al., 1997).

$S_{1}$-RNase fragments amplified from the cultivars Stark Redgold, Meigue Pantao, Caldesi 2000, and Snow Queen were cloned and sequenced, which further confirmed their identity; however, by comparing the sequences a single nucleotide polymorphism was detected in 'Caldesi 2000' and 'Snow Queen' (this form was labeled as $S_{1 \mathrm{~m}}$ ). A mutation in either part of the $S$-locus may confer self-compatibility on an otherwise self-incompatible Prunus species (Sassa et al., 1992; Sonneveld et al., 2005). The SNP lies within the conserved $\mathrm{C} 2$ region involving one of the histidine residues that is implicated in RNA catalysis (Broothaerts et al., 1995). However, the SNP represents a synonymous substitution and does not change the amino acid present at the position in the protein.

Ushijima et al. (2004) have found a 6.8-kbp insertion in the middle of the SFB coding region of a naturally occurring SC haplotype of japanese apricot. A part of the F-box gene was therefore amplified with consensus primers to find out whether self-compatibility can be attributed to a similar pollen-part mutation of the peach $S_{1}$-haplotype. As shown in Fig. 1D, all cultivars and hybrids gave a fragment of a similar size ( $\sim 700 \mathrm{bp})$ compared to the SI alleles in other Prunus species, indicating the absence of a notable deletion or insertion upstream from the $\mathrm{HVa}$ and $\mathrm{HVb}$ regions. However, further experiments involving DNA sequencing and expression analysis of the SFB gene are required to exclude the breakdown of pollen $S$ function in peach haplotypes.

The inheritance of $S$-alleles can be monitored in 'Caldesi 2000'. This cultivar and its parents 'Stark Redgold' and 'Snow Queen' share the same $S$-genotype $\left(S_{1} S_{1}\right)$, since both parents could only transmit the allele $S_{1}$ to their progeny. A P. persica $\times$ P. davidiana hybrid carries two alleles from which one had the same fragment sizes as the $S_{1}$-allele in peach. This fragment was sequenced and proved to be identical with the peach $S_{1}$-allele, while the other fragment was different from all known $S$-RNases and could be transmitted by the $P$. davidiana parent. Schematic structure of the isolated $S$-RNase alleles is shown in Fig. 3.

In the 25 peach accessions of different phenotype and origin, only two $S$-alleles were detected as compared to the 17-30 alleles described in the self-incompatible Prunus species(Hegedüs et al.,

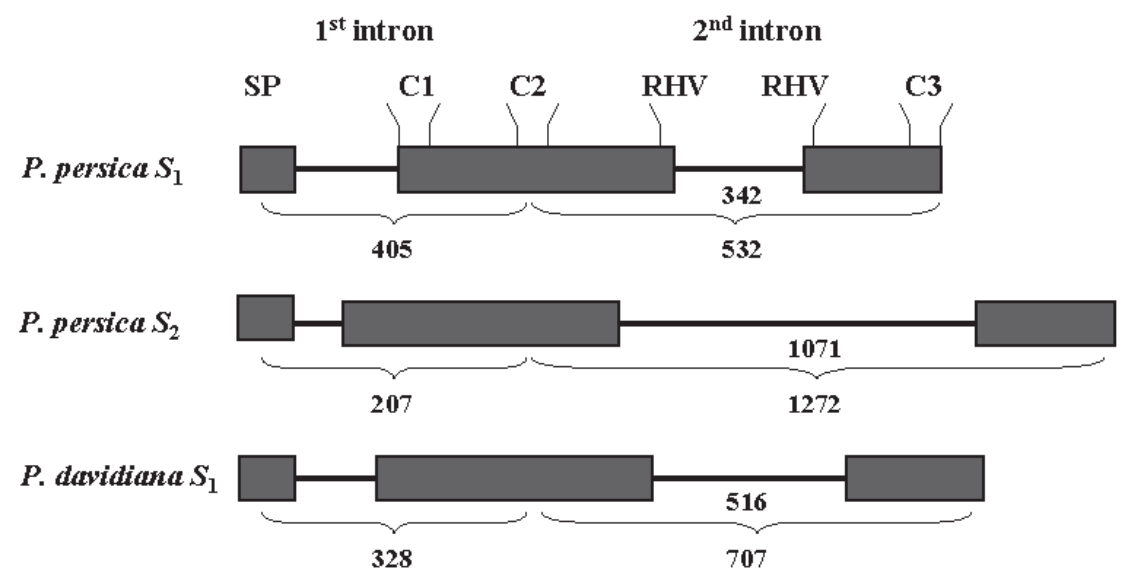

Fig. 3. Structure of the Prunus persica $S_{1^{-}}, S_{2}$ - and Prunus davidiana $S_{1}$-RNase alleles. Boxes and lines are exons and introns, respectively (not to scale). Sizes of the fluorescently labeled first intron regions were obtained on the automated sequencer; second intron region was sequenced, and the deduced intron lengths (above the brackets) are also marked; $\mathrm{SP}=$ signal peptide, $\mathrm{C} 1-3=$ conserved regions, $\mathrm{RHV}=$ rosaceous hypervariable region. 
2007). Self-compatibility in the Solanaceae may be a consequence of $S$-locus duplication, direct mutation of the $S$-genes, or changes outside the $S$-locus, as reviewed by de Nettancourt (2001). Our results indicate that the first two options do not seem possible although they cannot be ruled out. $S$-allele duplications or the presence of a centric fragment may lead to self-compatibility due to competitive interactions of $S$-proteins in the heteroallelic pollens (Lewis, 1947, 1961; Tsukamoto et al., 2005); however, these phenomena could not be demonstrated in Prunus species (de Nettancourt, 2001; Lewis, 1961). Furthermore, since heteroallelic pollen would result in an $S$-heterozygous progeny, the only heterozygous hybrid among the tested 25 accessions, as well as the fact that pollens of the tetraploid sour cherry (Prunus cerasus L.) carrying two different $S$-alleles functioned normally (Hauck et al., 2006), makes the $S$-locus duplications in peach very doubtful. Direct mutations were only excluded in a part of the $S$-RNase genes, and a considerable insertion being present in the SC cultivars of japanese apricot could not be shown in peach SFBs by PCR; however, the undoubtful exclusion of the pollen-part mutations in peach $S$-haplotypes requires further experiments.

Considering that self-compatibility of peach is not linked exclusively to either of the identified alleles, the action of genes outside the $S$-locus may also be assumed. Modifier genes have been shown to have determinant role in the $S$-RNase based SI system of solanaceous plants (Kao and Tsukamoto, 2004). $S$-RNases when introgressed from a SC Petunia Juss. cultivar into a self-incompatible one turned out to be functional, while transferring the $S$-RNase gene alone into SC species failed to confer the ability to reject self-pollen (Ai et al., 1991). A number of modifiers have been identified in the Solanaceae, which were placed in three groups (McClure et al., 2000). Group 1 factors affect the expression of $S$-locus genes, Group 2 factors leave $S$-RNase transcription unchanged but are required for pollen rejection, and Group 3 factors have a wider role in pollination; their null mutation would result in sterility while mutations in Groups 1 and 2 may cause a change from SI to SC behavior. As the peach $S$-RNase was shown to possess high activity in this study, self-compatibility may be due to a null mutation in a currently unidentified Group 2 factor. This mutation could have been present in the common ancestor of SC species (P. persica, P. davidiana, Prunus mira Koehne., etc.); it could have evolved independently; or it could have been introgressed from one another and accumulated in the population due to the resulting SC phenotype. A Group 2 factor (HT-protein) has recently been identified in Nicotiana L., Lycopersicon Mill., and Solanum L. (Cruz-Garcia et al., 2003).

In Prunus species, decisive proof is still not available for the existence of a similar modifier factor. Different degrees of selfcompatibility in almond $x$ peach hybrids (Socias i Company, 2004) and different degrees of fertility when crossing compatible pear (Pyrus communis L.) cultivars (Zuccherelli et al., 2002) were suspected to be due to the action of modifier genes. In 'Cristobalina', a spontaneous SC mutant cherry cultivar, Wünsch and Hormaza (2004) found that both of the two $S$-alleles could overcome the incompatibility barrier in self- and cross-pollinations when $S$ RNase and SFB sequences were the same as those described in SI cultivars carrying the same $S$-alleles.

The theories regarding self-incompatibility system in Prunus species are rapidly changing as the knowledge on the complexity of the bipartite model is evolving. Our results indicate that selfcompatibility is not exclusively attributable to mutations within the pistil or pollen component genes, but also to other genes outside the $S$-locus, which may influence the physical contact between the pollen and pistil $S$-proteins. The experiments presented here do not only supply valuable acquaintance with the molecular mechanisms of self-compatibility in peach, but also increase our knowledge regarding the function of the SI system in many cultivated Prunus species.

\section{Literature Cited}

Ai, Y., E. Kron, and T.H. Kao. 1991. S-alleles are retained and expressed in a self-compatible cultivar of Petunia hybrida. Mol. Gen. Genet. 230:353-358.

Altschul, S.F., T.L. Madden, A.A. Chaffer, J. Zhang, Z. Zhang, W. Miller, and D.J. Lipman. 1997. Gapped BLAST and PSI-BLAST: A new generation of protein database search programs. Nucleic Acids Res. 25:3389-3402.

Arulsekar, S., D.E. Parfitt, and D.E. Kester. 1986. Comparison of isozyme variability in peach and almond cultivars. J. Hered. 77:272-274.

Boškovic', R. and K.R. Tobutt. 1996. Correlation of stylar ribonuclease zymograms with incompatibility alleles in sweet cherry. Euphytica 90:245-250.

Boškovic', R., K.R. Tobutt, H. Duval, I. Batlle, F. Dicenta, and F.J. Vargas. 1999. A stylar ribonuclease assay to detect self-compatible seedlings in almond progenies. Theor. Appl. Genet. 99:800-810.

Broothaerts, W., G.A. Janssens, P. Proost, and W.F. Broekaert. 1995. cDNA cloning and molecular analysis of two self-incompatibility alleles from apple. Plant Mol. Biol. 27:499-511.

Cruz-Garcia, F., C.N. Hancock, and B.A. McClure. 2003. S-RNase complexes and pollen rejection. J. Expt. Bot. 54:123-130.

Cullinan, E.P. 1937. Improvement of stone fruits. U.S. Department of Agriculture Yearbook 1937. p. 665-748.

de Nettancourt, D. 2001. Incompatibility and incongruity in wild and cultivated plants. $2^{\text {nd }}$ ed. Springer-Verlag, Berlin.

Dicenta, F., E. Ortega, P. Martínez-Gómez, R. Boškovic', and K.R. Tobutt. 2002. Comparison of homozygous self-compatible seedlings in an almond breeding programme. Euphytica 124:23-27.

Dirlewanger, E., V. Pronier, C. Parvery, C. Rothan, A. Guye, and R. Monet. 1998. Genetic linkage map of peach [Prunus persica (L.) Batsch] using morphological and molecular markers. Theor. Appl. Genet. 97:888-895.

Faust, M. and B. Timon. 1995. Origin and dissemination of peach. Hort. Rev. 17:331-379.

Halász, J.,A.Hegedüs, R. Hermán, É. Stefanovits-Bányai, and A.Pedryc. 2005. New self-incompatibility alleles in apricot (Prunus armeniaca L.) revealed by stylar ribonuclease assay and $S$-PCR analysis. Euphytica 145:57-66.

Hauck, N.R., H. Yamane, R. Tao, and A.F. Iezzoni. 2006. Accumulation of non-functional $S$-haplotypes results in the breakdown of gametophytic self-incompatibility in tetraploid Prunus. Genetics 172:1191-1198.

Hegedüs, A., J. Halász, and A. Pedryc. 2007. The pistil component: A ribonuclease enzyme. In: J. Nyéki, M. Soltész, and Z. Szabó (eds.). Morphology of flowers, floral biology, regularities of fertilisation and fertility in fruit species. Akadémiai Kiadó, Budapest. (In press.)

Higgins, D., J. Thompson, T. Gibson, J. D. Thompson, D.G. Higgins, and T.J. Gibson. 1994. CLUSTAL W: Improving the sensitivity of progressive multiple sequence alignment through sequence weighting, position-specific gap penalties and weight matrix choice. Nucleic Acids Res. 22:4673-4680.

Kao, T.H. and T. Tsukamoto. 2004. The molecular and genetic bases of $S$-RNase-based self-incompatibility. Plant Cell 16:S72-S83.

Lewis, D. 1947. Competition and dominance of incompatibility alleles in diploid pollen. Heredity 1:85-108.

Lewis, D. 1961. Chromosome fragments and mutations of the incompatibility gene. Nature 190:990-991.

Martínez-Gómez, P., G.O. Sozzi, R. Sánchez-Pérez, M. Rubio, and T.M. Gradziel. 2003a. New approaches to Prunus tree crop breeding. Food Agr. Environ. 1:52-63.

Martínez-Gómez, P., S. Arulsekar, D. Potter, and T.M. Gradziel. 2003b. 
An extended interspecific gene pool available to peach and almond breeding as characterized using simple sequence repeat (SSR) markers. Euphytica 131:313-322.

Martínez-Gómez, P., S. Arulsekar, D. Potter, and T.M. Gradziel. 2003c. Relationships among peach, almond, and related species as detected by simple sequence repeat markers. J. Amer. Soc. Hort. Sci. 128:667-671.

Mau, S.-L., J. Raff, and A.E. Clarke. 1982. Isolation and partial characterization of components of Prunus avium L. styles, including an antigenic glycoprotein associated with a self-incompatibility genotype. Planta 156:505-516.

McClure, B.A., F. Cruz-Garcia, B.S. Beecher, and W. Sulaman. 2000. Factors affecting inter- and intra-specific pollen rejection in Nicotiana. Ann. Bot. 85:113-123.

Miller, P.J., D.E. Parfitt, and S.A. Weinbaum. 1989. Outcrossing in peach. HortScience 24:359-360.

Monet, R.,A. Guye, and M. Roy. 1996. Effect of inbreeding and crossing inbred lines on the weight of peach fruit. Acta Hort. 374:77-82.

Ortega, E., B.G. Sutherland, F. Dicenta, R. Bošković, and K.R. Tobutt. 2005. Determination of incompatibility genotypes in almond using first and second intron consensus primers: Detection of new $S$ alleles and correction of reported $S$ genotypes. Plant Breeding 124:188-196.

Roiz, L. and O. Shoseyov. 1995. Stigmatic RNase in self-compatible peach (Prunus persica). Intl. J. Plant. Sci. 156:37-41.

Romero, C., S. Vilanova, L. Burgos, J. Martínez-Calvo, M. Vicente, G. Llácer, and M.L. Badenes. 2004. Analysis of the $S$-locus structure in Prunus armeniaca L. Identification of $S$-haplotype specific $S$-RNase and F-box genes. Plant Mol. Biol. 56:145-157.

Sassa, H., H. Hirano, and H. Ikehashi. 1992. Self-incompatibility-related RNases in styles of japanese pear (Pyrus serotina Rehd.) Plant Cell Physiol. 33:811-814.

Scorza, R., S.A. Mehlenbacher, and S.W. Lightner. 1985. Inbreeding and coancestry of freestone peach cultivars of the eastern United States and implications for peach germplasm improvement. J. Amer. Soc. Hort. Sci. 110:547-552.

Scott, D.H. and J.H. Weinberger. 1944. Inheritance of pollen sterility in some peach varieties. Proc. Amer. Soc. Hort. Sci. 9:187-188.
Socias i Company, R. 2004. The contribution of Prunus webbii to almond evolution. PGR Nwsl. 140:9-13.

Sonneveld, T., K.R. Tobutt, and T.P. Robbins. 2003. Allele-specific PCR detection of sweet cherry self-incompatibility (S) alleles S1 to S16 using consensus and allele-specific primers. Theor. Appl. Genet. 107:1059-1070.

Sonneveld, T., K.R. Tobutt, S.P. Vaughan, and T.P. Robbins. 2005. Loss of pollen- $S$ function in two self-compatible selections of Prunus avium is associated with deletion/mutation of an $S$ haplotype-specific F-box gene. Plant Cell 17:37-51.

Sutherland, B.G., T.P. Robbins, and K.R. Tobutt. 2004. Primers amplifying a range of Prunus $S$-alleles. Plant Breeding 123:582-584.

Szabó, Z. and J. Nyéki. 2000. Floral biology and fertility in peaches (review article). Intl. J. Hort. Sci. (Hungary) 6:10-15.

Tao, R., H. Yamane, H. Sassa, H. Mori, T.M. Gradziel, A.M. Dandekar, and A. Sugiura. 1997. Identification of stylar RNases associated with gametophytic self-incompatibility in almond (Prunus dulcis). Plant Cell Physiol. 38:304-311.

Tsukamoto, T., T. Ando, H. Watanabe, E. Marchesi, and T.H. Kao. 2005. Duplication of the $S$-locus F-box gene is associated with breakdown of pollen function in an $S$-haplotype identified in a natural population of self-incompatible Petunia axillaris. Plant Mol. Biol. 57:141-153.

Ushijima, K., H. Sassa, R. Tao, H. Yamane, A.M. Dandekar, T.M. Gradziel, and H. Hirano. 1998. Cloning and characterization of cDNAs encoding $S$-RNases from almond (Prunus dulcis): Primary structural features and sequence diversity of the $S$-RNases in Rosaceae. Mol. Gen. Genet. 260:261-268.

Ushijima, K., H. Yamane, A. Watari, E. Kakehi, K. Ikeda, N.R. Hauck, A.F. Iezzoni, and R. Tao. 2004. The $S$ haplotype-specific F-box protein gene, $S F B$, is defective in self-compatible haplotypes of Prunus avium and P. mume. Plant J. 39:573-586.

Wünsch, A. and J.I. Hormaza. 2004. Genetic and molecular analysis in Cristobalina sweet cherry, a spontaneous self-compatible mutant. Sexual Plant Reproduction 17:203-210.

Zuccherelli, S., P. Tassinari, W. Broothaerts, S. Tartarini, L. Dondini, and S. Sansavini. 2002. S-allele characterization in self-incompatible pear (Pyrus communis L.). Sexual Plant Reproduction 15:153-158. 